\title{
A pioneering model of modernization during the Republican era: Eskişehir Sugar Factory (1933) industrial heritage
}

\author{
B. Üstün, F. Kolsal \& A. D. Bulut \\ Department of Architecture, Anadolu University, Turkey
}

\begin{abstract}
Industrial buildings constructed by different cultures during the development process of the cities, contribute to the creation of the urban identity. The industrial buildings and settlements, which generate the colour, smell and sometimes the sound of the city, are multi-functional structures meeting the needs of the people living in that city. Those structures, in addition to being productive spaces, serve as catalysts for the financial and socio-cultural development of the city. Frequently, they lose their importance after an active usage period, because of rapid technological changes.

The subject matter of this paper is the Settlement of the Eskişehir Sugar Factory which is a prototype of Republican era modernization. It provides very valuable information within the definition of "industrial heritage" regarding the history and the urban life of the city.

Keywords: industrial heritage, company towns, Turkish modernization, Republican era modernization, industrial settlements of Republican era, Eskişehir Sugar Factory.
\end{abstract}

\section{Introduction}

Eskişehir Sugar Factory, designed by the German Architect, Frederick August Breuhaus in 1933 is located near the railway and the Porsuk River, which are two significant elements of the identity of Eskişehir. It is a settlement in which different cultures participate in productive activities. After the foundation of the Sugar Factory, one of the pioneer establishments of the city, new spatial organizations occurred in the residential and commercial pattern of the city. With its multifunctionality, the Sugar Factory is one of the first settlements of the 
Republican era that meets social, cultural, educational needs and the needs for health and accommodation of the workers, showing a model of a micro scale city (company town). Moreover, it is a very important example with additional parts constructed during different periods having specific architectural qualities.

Most of these industrial heritage belonging to that era (Early Republican Period) have been demolished and destroyed owing to the uncontrolled urban sprawl, decentralization of the cities, the natural life-time or political decisions. A few rare examples still remain without any modification.

Therefore, the aim of this paper is to reveal the architectural and historical value of the Sugar Factory, which had preserved its originality up to now and retain its unchanged qualities by having been registered as an industrial heritage. To demonstrate this, firstly the above-mentioned aspects of the settlement will be clearly stated via field study including literature reviews, historical research, observations in the area, current and old photographs of the buildings and some internationally successful examples of conservation of industrial heritage. The second section will explain the modernization and industrialization in the Republican era to create the frame and base of the study. In the following sections, the qualities of the Factory are expressed. Finally, international examples will be scrutinized to compare the different approaches in transferring a group of buildings creating an identity to the next generations. In conclusion, regarding all aspects of the settlement, a correlation will be studied between those examples and the Sugar Factory.

\section{Modernization period of the Republican era and the development of industrial buildings}

The modern movement of the Republican era can be described as the construction of a nation in social, metaphoric and physical terms, during which cities and spaces were transformed according to modernization. Additionally, those transformed spaces strengthened the idea of modern life. Modernization, as a universal and liberalizing concept regarding its relation and bonds with the past, was a very crucial goal of the newly established Republican Regime that wanted to leave behind the inoperative systems of the Ottoman Empire. Therefore, in the Türkiye which emerged as a nation state, modernization was accepted as a governmental policy by putting modern ideas in the political, financial, sociological contexts of society. As a first step, the necessity for financial progress had resulted in the development of industrial buildings. The period of Republican modernization has a strong relation with the development of industrial buildings [1].

Industrial development increased rapidly especially from 1932 and 1938, and had been promoted mostly by governmental investment. These investments of this period, one of which was Eskişehir Sugar Factory, could be named as pioneering settlements, since they had further significance besides being created for specific spaces and functions. Considering the effect of those spaces, the pioneering settlements had been successful in enhancing a new way of life and 
ideology. They also have some sort of common qualities regarding the soul and architecture of the period.

First of all, it could be stated that the industrial outputs of the period had been organized within a settlement holding units of different functions other than production. Analysing the spatial qualities of Early Republican industrial complexes, Zeybekoğlu [2, p. 223] indicates that these settlements designed as to meet the needs of workers are very similar to the "company towns", emerged as an important industrial model in Europe and America during the 19th century.

Similarly, according to Alexander [3], the factories represent the construction of an ideal state, a microcosm of a harmonious community participating in a shared culture and contributing towards national, industrial development. Both words "construction" and "fabrication" lend themselves equally to the filling-in of a space either geographical or conceptual. From this description, it could be said that the industrial buildings of Republican era were productive spaces generating modern ideals as well.

The location of the settlements is such that they are all in the periphery, out of the existing patterns of the city. Like in Eskişehir Sugar Factory case, this situation has now changed owing to the fact that the surroundings have become urbanised.

Another common quality of these settlements is the rational design approach which fits with the nature of modernism and production. For instance, the grid circulation axes and the forms of buildings in the settlements are a result of this approach.

In the settlements, an extroverted design approach is adopted demonstrating a secular, collective spatial composition divided into productive, social and residential units. Social units are located accordingly to provide access in and out of the settlement; residential units are placed far enough from the main circulation axle due to noise and pollution factors, but close enough for pedestrian use and security issues. A rational approach in the plan and in its third dimension is dominant for all the building blocks inside the settlements [4].

The residential blocks occupy rather big portions of land in the settlements surrounded by green spaces. These residential units which introduced a model for modern living are especially positioned, so as to be easily perceived from outside the settlement. This sensitivity confirms the didactic and paternalist ideas of Republican Architecture [5].

Having a physical connection to the city by the design of the circulation routes, the social spaces underlines the urban significance of such settlements through the same didactic principle. The uses of these settlements stresses their social dimension. Those structures holding educational and service buildings besides social and recreative units available for the city-dwellers are samples of the ideology of modernization [1].

All the factory settlements in Anatolia, constructed during the accelerated industrial period following the proclamation of Republic, testify to the abovementioned concepts. The importance of Eskişehir as an industrial city is explained in the following section. 


\section{An industrial heritage: Eskişehir Sugar Factory settlement (1933)}

\subsection{The development of industry in the city}

The Anatolian city of Eskişehir has a history stratified by various civilizations and cultures. During the reign of the Hittites around 2000 B.C., it was a feudal dwelling due to its geographical importance. The dwellings were called Dorylaion in 1200 B.C. and were under the rule of Phrygians. There after it was ruled by Lydians and by Persians in 546 B.C. The city had been dominated by Hellenism until 323 B.C. In 190 B.C. it was conquered by Rome and after the Roman Empire it was split in two in 395 B.C, the city remained under the Byzantium rule. It was ruled by the Seljuqid Empire after 1074 and by the Ottoman Empire after 1289 [6, 7], [8, pp. 1-3].

Having a strategically crucial location in the commercial and financial sense through its history, fertile lands and the intersection of the road networks dividing Anatolia across east and west, north and south settlement, Eskişehir has always been under a stream of migration. Therefore the city gained commercial and military significance.

There were two fundamental elements dominating the structure of the city. One is the railway introduced in 1890s, the other is the Porsuk River. Those one natural and one man-made elements facilitate the comprehension of the urban structure of Eskişehir, because the railway constructed during the Ottoman Period had a great role in creating an "industrial city". Another factor is the fertile lands around Porsuk River.

The development of industry in Eskişehir has been mainly affected by the governmental establishments founded in the beginning of the $20^{\text {th }}$ century. One of the important aspects causing the industrial progress of the city was the qualified labour force raised in those establishments. Industry in Eskişehir was shaped by agricultural and natural resources during the early Republican period. During that period, great scale flour mills were constructed in Eskişehir which is an important grain region. In addition to that, being a substantial crude material of Eskişehir, clay had caused an increase in investments based on the soil in the city. In 1928, after the expropriation of the locomotive plant which had been set up during the Berlin-Baghdad railway construction in 1894, industrial development had accelerated and the first steps for metal and machinery industry were taken. Similarly, mining became another important sector developed by governmental investments in the plentiful underground resources of Eskişehir.

Besides these improvements, other appropriate qualities of Eskişehir had led to extra governmental institutions to be set up in the city by means aid supported by America.

The 1930s was a period in which new public initiatives participated in the industrial facilities of Eskişehir and the growth of the private organizations continued. Through this period the conventional industrial branches such as flour and tile-brick factories had enlarged their capacities reaching a notable size nationwide. Eskişehir Sugar Factory had also been founded during this same 
period, either causing new investments to be done related to sugar industry; or contributing to the economy of the city with the qualified labour force it created [9].

While various factories and settlements founded by the private sector and the state had contributed to the development of the city, the near surroundings of these settlements were transformed socio-culturally and spatially. Nevertheless industrial spaces at the end of their physical lives, can be transformed. All these changes causing functional modifications, brings about a memory and culture of the city and they all create very important data in transferring this memory to the next generations. In $21^{\text {st }}$ century, Eskişehir has a prosperous building heritage regarding its industrial archaeology (both in single factory and settlement scale). The settlement of Sugar Factory is a fundamental piece of this heritage.

\subsection{Eskişehir Sugar Factory settlement (1933)}

When the Turkish, German and Austrian architects considered worked throughout Europe and Türkiye during the first half of 20th century, the multinational configuration of the modern city and its structural culture was revealed. After the proclamation of the Republic, in order to reconstruct the modern institutions and educational system, the Kemalist Regime invited hundreds of specialists to Türkiye mainly from the German speaking countries [10]. Therefore, in this period, while two different cultures were living together, they also culturally affected each other.

In this context, The Sugar Factory, having a crucial impact on the development of the city, was created by the participation of Türkiye İş Bank (51\%), Ziraat Bank (24\%), and Industry and Mine Bank (25.5\%) by Anatolian Sugar Factories Turkish Limited Company in order to produce ethyl alcohol, subsidiary materials and sugar and sugar beet industry. The decision to establish the factory had been taken on the $1^{\text {st }}$ October in 1932. From this date on, twomonths long examinations were carried out and the iron to be used in the construction and the factory machines were ordered from the German company 'Maschinenfabrik Buckau R. Molf Aktein Gesellschaft Magburg'. The first works such as identification of the place for the construction, the purchase of the land and the procedures for the construction and the transportation were finalised in the following period. On $1^{\text {st }}$ February 1933 the foundation of the factory had been laid, on $1^{\text {st }}$ April of the same year construction began and the whole buildings were completed in the very short time of six and a half months. The establishment started to work on the $20^{\text {th }}$ October in 1933 (fig. 1). The opening ceremony took place on $5^{\text {th }}$ December in 1933 [2, p. 246].

The land on which the settlement lies (fig. 2), has a 2627 meters boundary along Porsuk River, 1510 meters side along Eskişehir Aeroplane Factory, 2745 meters boundary on the Ankara-Eskişehir railway and 1228 meters bordering the city. It is an area with a surface of 3.653 .708 meter squares [12].

It can be seen from the site plan (fig. 3), (divided into two by EskişehirAnkara Highway), that the units of production are located on the side of railway and the administrative units and social units such as residential housing, sport 


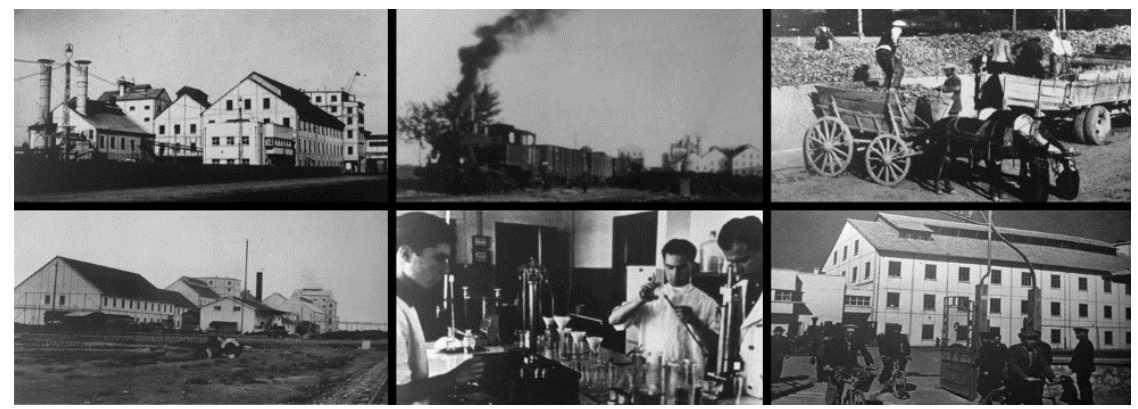

Figure 1: Eskişehir Sugar Factory in the early years [8, p. 136, 11].

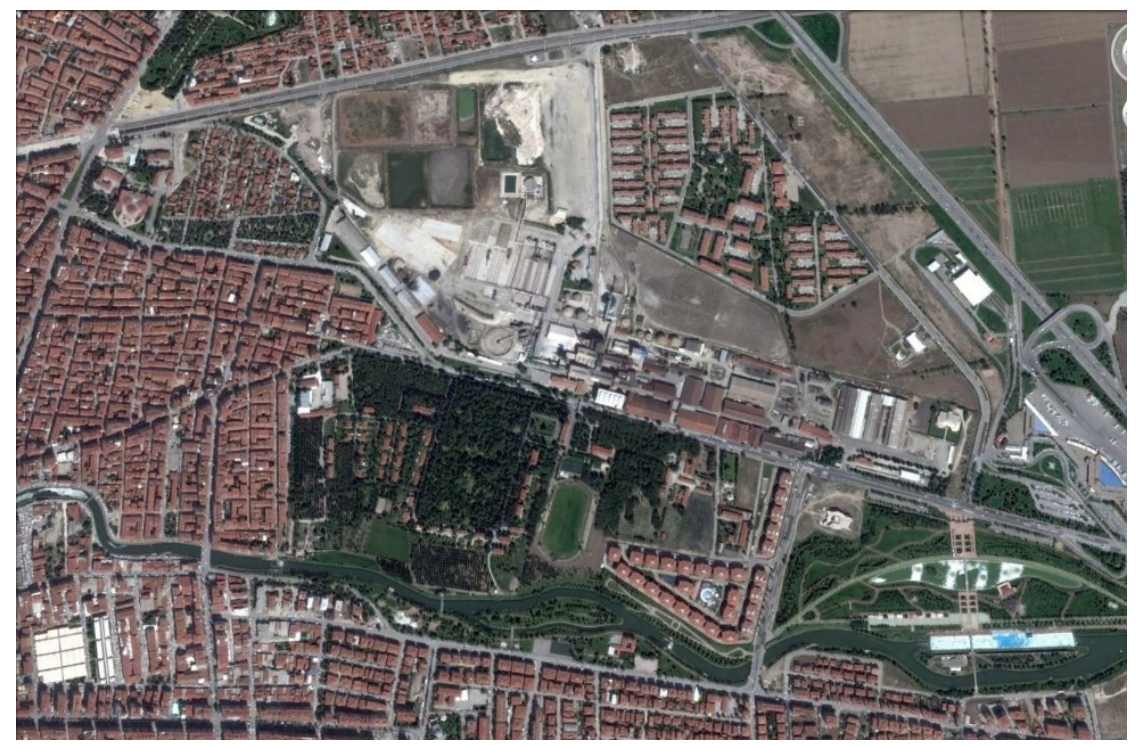

Figure 2: Sugar Factory settlement and nearby (source: Google earth, www.googleearth.com).

fields, school and hospital are placed within an intensive green area on the opposite side of the units of production. The portion of the land along Porsuk River was utilized for agricultural purposes especially for the production of sugar beet. There are individual houses, guest house, sport fields, refectory, pavilions for single workers (fig. 4), factory buildings, repositories, maintenance hall, workshops, carpenter hall, a dormitory for girls, and repair halls in the settlement. In early periods, the hospital in the settlement had served for the people in the city as well. This building was transformed into a dormitory for girls. The building used as refectory today was constructed as a cinema. The guest house instead had held the administrative functions since the beginnings [13]. 


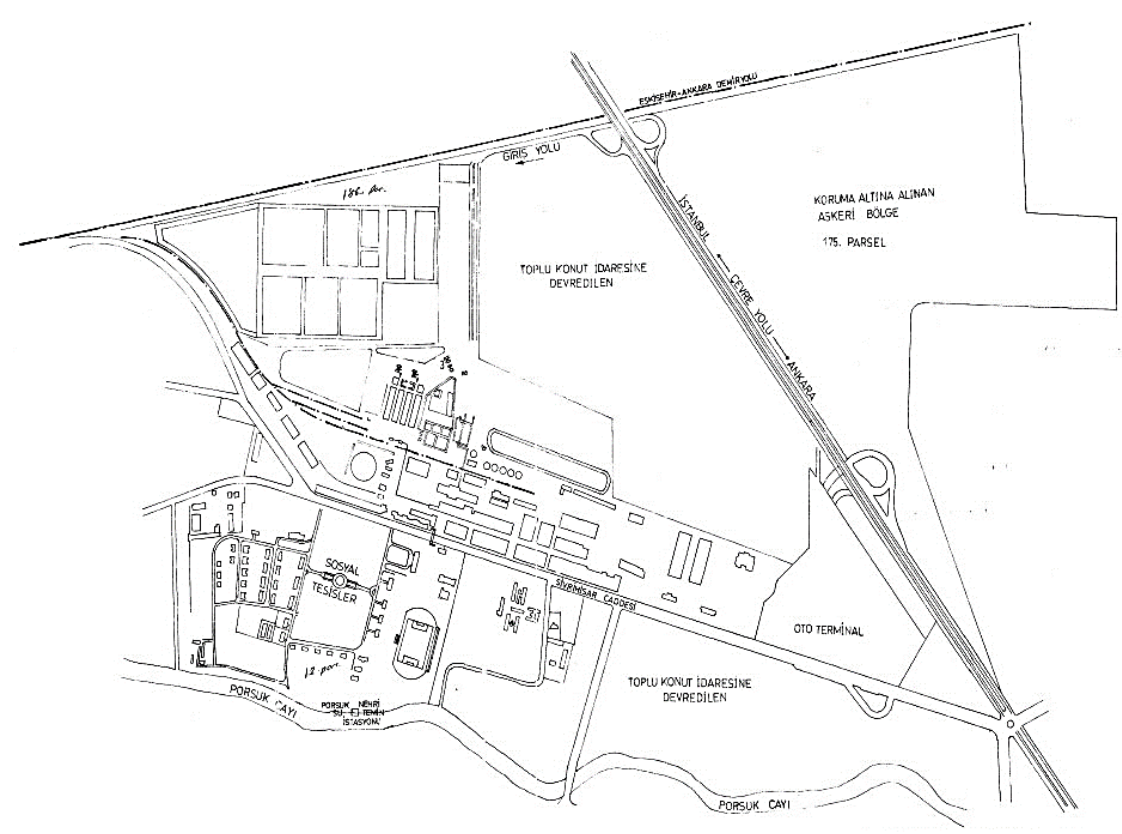

Figure 3: Site plan of Eskişehir Sugar Factory settlement (source Eskişehir Sugar Factory photography archive, 2010).

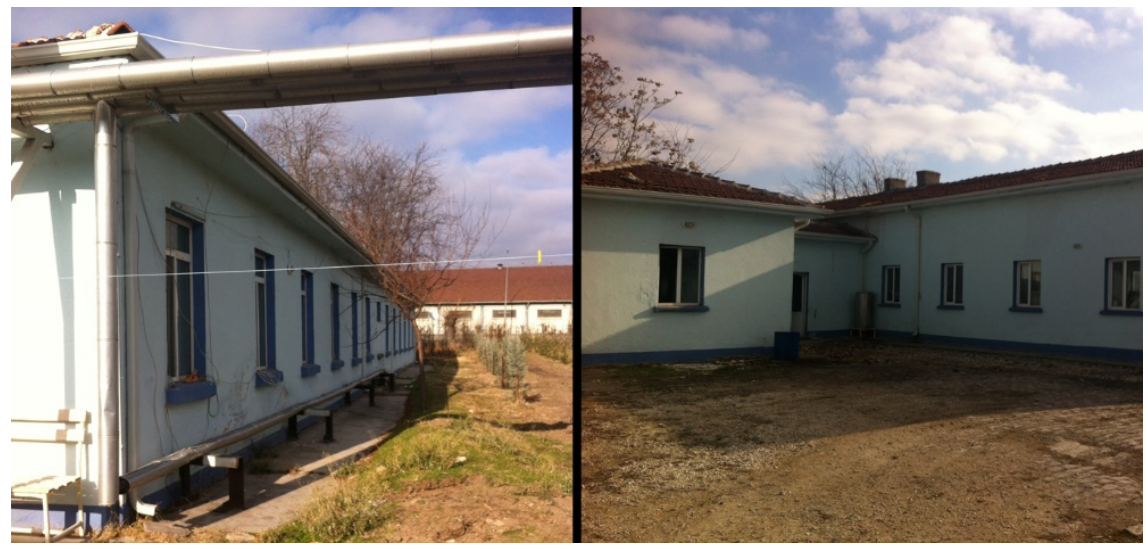

Figure 4: Pavilions for single workers are located far from housing units of workers with families. Housing units, built as single-storey and row houses, also allow common usage in their service areas (source: B. Üstün and A. Gülle personal photography archive, 2013). 


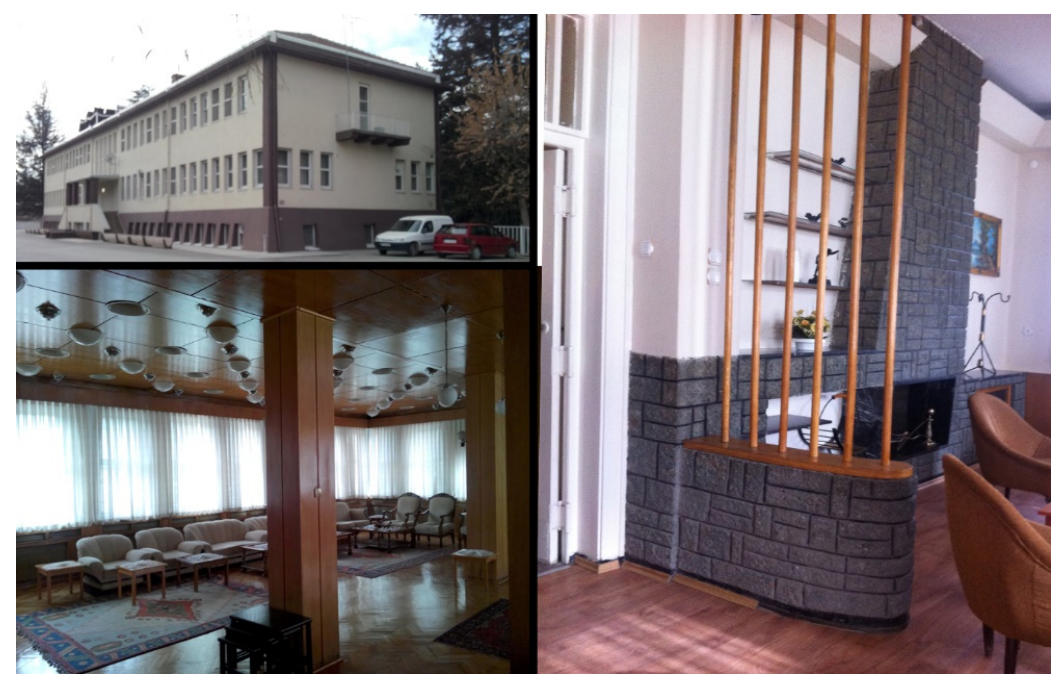

Figure 5: Guesthouse (socio-culture facilities) used as an administrative building in early years. It reflects the modernist spirit of the Republican era in its interior furnishings (source: B. Üstün and A. Gülle personal photography archive, 2013).

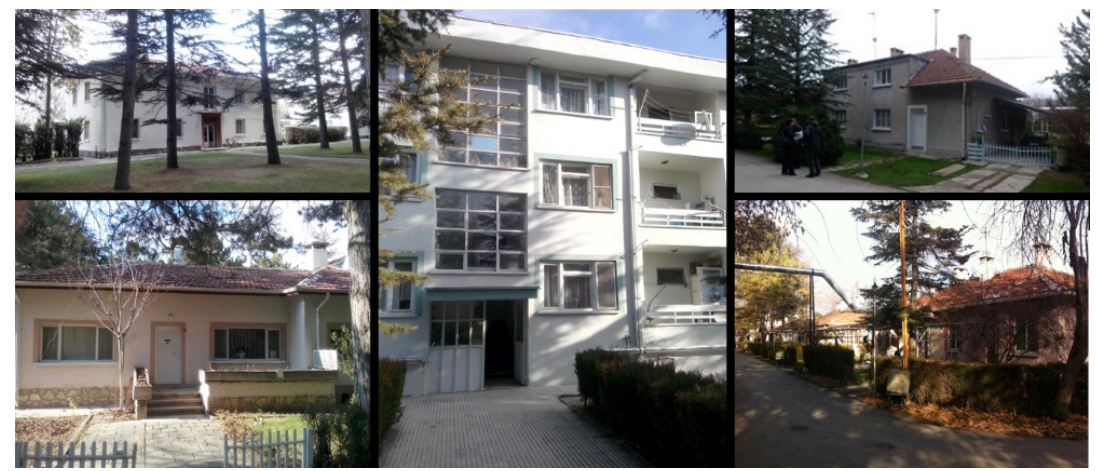

Figure 6: Individual houses, incorporating different housing typologies, and separated from the manufacturing facility by a grove. Built as lowrise and located near sports and socio-culture areas of the settlement, these houses are built in different sizes for managers, assistant managers and engineers; they follow the garden-city theory in being low-rise and having gardens. These German designed houses are different from those in traditional Turkish culture, like in their usage of roof space, storage in the kitchen, basement floor reached from the kitchen, wc and laundry entrance from the kitchen etc. Apartment style houses were built as a result of insufficient low-rise houses. Residential parts of the settlement are registered with the Protection Committee (source: B. Üstün and A. Gülle personal photography archive, 2013). 


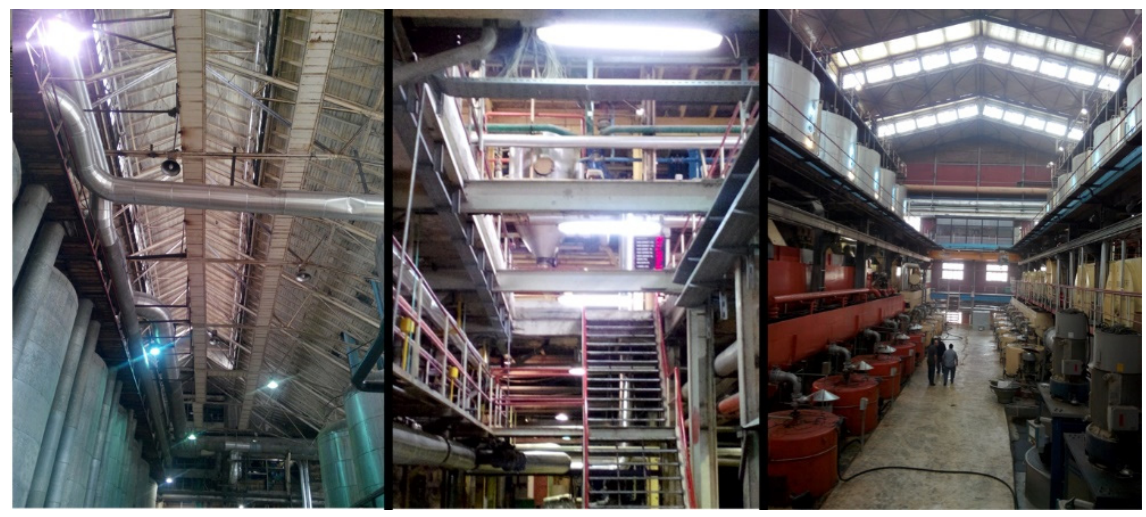

Figure 7: Factory Manufacturing Facility begins production in September and finishes after 3-4 months every year. In spite of containing innovative machinery based on technological developments, the main building structure has not changed (source: B. Üstün and A. Gülle personal photography archive, 2013).

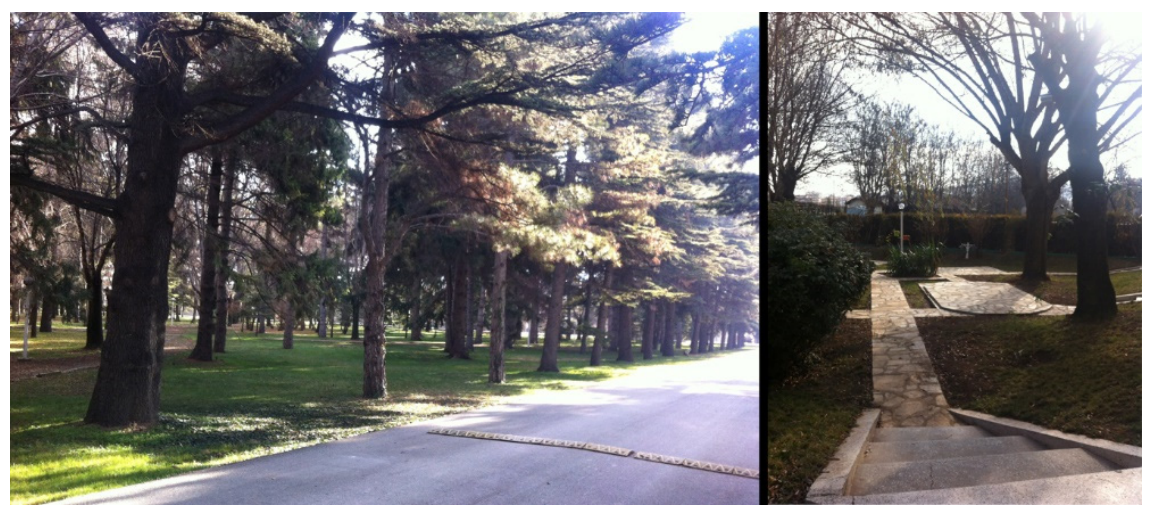

Figure 8: The greenest zone of the city is still the Sugar Factory settlement. A large grove in the middle of the housing zone and the green areas between the single-storey houses are used as a children's playground and sport areas (source: B. Üstün and A. Gülle personal photography archive, 2013).

\section{Conclusion and suggestions}

Industrial structures could be seen as components making an indirect contribution to the process of industrial production. The reason for these structures is the need for a space which renders the production possible. Thus, it is expected that this space supports the functional and economical aspects of the production and results in efficient production under appropriate working conditions [14]. This kind of industrial building both as a single factory or in 
settlements operate throughout different periods and has a defined useful life. Therefore they could be evaluated within the "industrial heritage" concept due to the values they hold. Industrial heritage involves the remains of industrial culture holding historical, technological, social, architectural and scientific values [15].

The conservation of the industrial heritage which is significant for the memory and identity of the cities requires sufficient approaches than the conventional methods applied for cultural heritage. The wholeness of the industrial heritage is a precondition to the aesthetic values. Consequently the essential value for conservation ought to consider the conditions for the existence and sustainability of the heritage. Hence, for an industrial heritage, along with all other qualities, the value of wholeness is the key quality embodying all other values to be conserved [16].

In this context, conservation and preservation studies applied in America and England to the first models of industrial settlements (company towns) could set an example for Eskişehir. For instance, Lowell textile settlement, owns a crucial place in the industrial revolution of America, having had its most brilliant economic and social period at the beginning of $20^{\text {th }}$ century. Industry declined after World War II, affecting the structure of the city which was strongly linked with its industrial bases. The immigrants coming from different countries started to dwell in the abandoned buildings. The first conservation attempts begun in 1970 and Lowell was declared a "national park" by its city council [18]. Similarly, the Pullman settlement designed in 1883 had terminated productive activities in 1982. It was registered as "historical heritage" by the Illinois Historic Preservation Agency of America in 1970. The evaluation process still continues for it to be used as a protected national park.

The first planned industrial organization in England was Saltaire Work Settlement which was founded by Sir Titus Salt between 1850 and 1863. The settlement, in which production stopped in 1986, was accepted as "World Heritage" by UNESCO in 2001. As a result of this all of the buildings belonging to the company town are now listed. Those buildings of the textile settlement renovated in an innovative manner are currently being used as a multifunctional art centre [18].

In this respect, when the meaning of the Sugar Factory is considered for Eskişehir, it can be seen that the settlement is a prototype and a micro scale dwelling for the city with its multi-functional structure meeting social, cultural, educational and other needs of the workers. It had created an economic and social dynamism for Eskişehir. It is a very valuable piece of industrial heritage describing the various architectural languages owing to the additional buildings of different eras. The individual housing units in the settlement are also listed, although a rigid conservation criteria is not valid in this case. The conservation of the settlement is important for the memory of the city and for its uniqueness [19]. 


\section{References}

[1] Kolsal, F., Cumhuriyet Dönemi Modernleşmesinin Bir Sanayi Yapısı Üzerinden Kentsel ve Mekansal Olarak Okunması: Aydın Tekstil Yerleşkesi, 2015, Institute of Science, Anadolu University, Eskişehir, Turkey.

[2] Zeybekoğlu, S., Erken Cumhuriyet Döneminde Sanayi Komplekslerinin Mekânsal Analizi: Nazilli, Kayseri, Bursa, Eskişehir, Fabrikada Barınmak, Erken Cumhuriyet Dönemi'nde Türkiye'de İş̧i Konutları; Yaşam, Mekan ve Kent, ed A. Cengizkan, Arkadaş Yayınevi, Ankara, 2009.

[3] Alexander, C., Personal States; Making Connections Between People and Bureaucracy in Turkey, Oxford University Press, pp. 129, 2002.

[4] Arıtan, Ö., Sümerbank Yerleşkeleri: Cumhuriyet Modernleşmesi'nin İdeolojik Varyasyonlarına İlişkin Mekânsal Bir Okuma, Fabrikada Barınmak, Erken Cumhuriyet Dönemi'nde Türkiye'de İş̧̧i Konutları; Yaşam, Mekan ve Kent, ed A. Cengizkan, Arkadaş Yayınevi, Ankara, pp. 211, 2009.

[5] Arıtan, Ö., Kapitalist/Sosyalist Modernleşme Modellerinin Erken Cumhuriyet Dönemi Mimarlığının Biçimlenişine Etkileri-Sümerbank KİT Yerleşkeleri Üzerinden Yeni Bir Anlamlandırma Denemesi, 2004, Institute of Science, Dokuz Eylül University, Izmir, Turkey.

[6] Albek, S., Dorylaion'dan Eskişsehir'e, Eğitim, Sağlık ve Bilimsel Araştırma Çalışmaları Vakfı Yayınları, pp. 33-43, 1991.

[7] Ertin G., Eskişehir Kentinde Yerleşmenin Evrimi, Anadolu Üniversitesi Yayınları No. 773, pp. 1-30, 1994.

[8] Sarıöz, P., Bir Zamanlar Eskişehir, Esbank Yayınları, 1997.

[9] Eskişehir Sanayi Odası, http://www.eso.org.tr/

[10] Akcan, E., Çeviride Modern Olan Şehir ve Konutta Türk-Alman Ilisşkileri, Yapı Kredi Yayınları, p. 9, 2009.

[11] Kılıç, L., Anılarda Eskişehir, Eskişehir Anadolu Rotary Kulübü, pp. 6869, 1997.

[12] Turan, V., 30.Yılında Türkiye Şeker Sanayii, 1926-56, Türkiye Şeker Fabrikaları A.Ş. Neşriyatı No: 48, p. 58, Ankara, 1958.

[13] Üstün, B., Eskişehir'de Modernizm ve Kentsel Gelişme Sürecinde Gerçekleştirilen Toplu Konut Alanlarında Konut Tipolojileri ve Yerleşim Örüntülerindeki Değişimlerin Değerlendirilmesine Yönelik Bir Çalışma, Anadolu Üniversitesi Bilimsel Araştırma Projeleri Proje No: 80211, 2010.

[14] Saner, M.\& Severcan, Y. C., Fabrikada Zorunlu Sorumlu Olarak Barınmak: Ankara Maltepe Elektrik ve Havagazı Fabrikası Konutları, Fabrikada Barınmak, Erken Cumhuriyet Dönemi'nde Türkiye'de Isş̧i Konutları; Yaşam, Mekan ve Kent, ed A. Cengizkan, Arkadaş Yayınevi, Ankara, pp. 46, 2009.

[15] International Council on Monuments and Sites (ICOMOS) Web Site, $\mathrm{http}: / /$ www.international.icomos.org/18thapril/2006/nizhny-tagil-chartere.pdf 
[16] Kaya, B., Endüstri Mirasımızın Korunmasında Planlama Yaklaşımı, Uzmanlık Tezi, 2012.

[17] http://en.wikipedia.org/wiki/Lowell, Massachusetts

[18] Minnery, J., Research From the Field: Model Industrial Settlements and Their Continuing Governance, Planning Perspectives, 27 (2), pp. 309-321, 2012.

[19] Üstün, B., Eskişehir Devlet Demir Yolları Yerleşkesi, Lojman Konutları Plan Tipolojileri Üzerine Bir Çalışma, Tasarım \& Kuram dergisi, 7 (1112), pp. 63, Mimar Sinan Güzel Sanatlar Üniversitesi, Mimarlık Fakültesi Dergisi, 2011. 